\title{
FAKTOR-FAKTOR YANG MEMPENGARUHI SIKLUS MENSTRUASI PADA REMAJA PUTRI TINGKAT III
}

\author{
Aesthetica Islamy ${ }^{1}$, Farida ${ }^{1}$ \\ ${ }^{1}$ STIKes Hutama Abdi Husada Tulungagung \\ tika.aesthetica@gmail.com
}

\begin{abstract}
ABSTRAK
Remaja putri sering mengalami gangguan menstruasi terutama pada tahun pertama setelah menarche.Gangguan terbanyak berupa keterlambatan siklus menstruasi (80\%).Faktor risiko gangguan siklus menstruasi adalah hormonal, status gizi, Indeks Massa Tubuh (IMT), dan tingkat stres.Tujuan penelitian untuk mengetahui faktor yang paling dominan mempengaruhi siklus menstruasi pada remaja putri tingkat III di STIKes Hutama Abdi Husada Tulungagung.Desain penelitian berupa analitik cross-sectional dengan jumlah sampel sebanyak 40 responden.Analisis data dengan uji statistik Chi-square dan multivariate analysis. Hasil penelitian menunjukkan bahwa terhadapat hubungan antara tingkat stres $(\mathrm{RP}=4,7(95 \% \mathrm{CI} 1,1-20,0) ; \mathrm{p}=0,015)$ dan status gizi $(\mathrm{RP}=2,8(95 \% \mathrm{CI}$ $1,6-4,8) ; p=0,026)$ dengan siklus menstruasi. Analisis multivariat menunjukkan bahwa variabel yang paling besar pengaruhnya dalam siklus menstruasi adalah status gizi dan tingkat stres.Kesimpulan dari penelitian bahwa remaja putri yang mengalami stres dan memiliki status gizi tidak normal dapat berdampak pada siklus menstruasi. Rekomendasi bagi dinas kesehatan dan puskesmas diharapkan lebih meningkatkan pemberian informasi dalam peningkatan kesehatan reproduksi terutama pada gangguan siklus menstruasi.
\end{abstract}

Kata kunci :cross-sectional, faktor risiko, menstruasi, status gizi, stres

\section{FACTORS THAT INFLUENCE THEMENSTRUATION CYCLE IN YOUNG WOMEN LEVEL III}

\begin{abstract}
Menstrual disorders was a common problem for teenagers. The menstrual cycle in adolescents was often irregular in the first year after menarche. Approximately $80 \%$ of teenage girls who experience delayed menstrual cycle and 7\% who experienced menstruation faster. There were several factors that can cause menstrual cycle disorders including hormonal disorders, nutritional status, IMT, and stress. The aim of this research was to find out the most dominant factors which caused Menstruation Cycle in Young women. The study design was in the form of cross-sectional analytic with a total sample of 40 respondents. Data analysis with Chi-square and multivariate analysis. The results showed that there was a relationship between stress levels $(R P=4.7(95 \% C I 1.1-20.0) ; p=0.015)$ and nutritional status $(R P=2.8(95 \% C I 1.6-4,8) ; p=0.026)$ with the menstrual cycle. Multivariate analysis showed that the variables that had the greatest influence on the menstrual cycle were nutritional status and stress levels. The conclusion of the study is that young women who experience stress and have abnormal nutritional status can have an impact on the menstrual cycle. Recommendations for health offices and health centers are expected to increase information provision in improving reproductive health, especially in disorders of the menstrual cycle.
\end{abstract}

Keywords: cross-sectional, risk factor, menstruation, nutritional status, stress

\section{PENDAHULUAN}

Siklus menstruasi adalah tanda proses kematangan organ reproduksi yang dipengaruhi oleh hormon tubuh. Peranan siklus menstruasi berhubungan dengan tingkat kesuburan perempuan (Sinha et al., 2011). Siklus ini secara teratur berlangsung jika seorang remaja telah menginjak usia $17-18$ tahun (Patil et al, 2013) namun dapatjuga terjadi setelah 3 - 5 tahun dari usia menarche (Rigon et al.,2012). Pola menstruasi normal berlangsung setiap 21 - 35 hari sekali, adapun lama hari menstruasi dapat berlangsung selama $3-7$ hari (Aryani, 2010). 
Gangguan siklus menstruasi terdiri dari 2 macam, yaitu polimenorea dan oligomenorea. Polimenorea adalah siklus menstruasi dengan jumlah rentang hari kurang dari 21 hari dan atau volume darah sama atau lebih banyak dari volume darahan menstruasi biasanya. Gangguan ini mengindikasikan gangguan pada proses ovulasi, yaitu fase luteal yang pendek. Polimenorea menyebabkan unovulasi pada wanita karena sel telur tidak dapat matang sehingga pembuahan sulit terjadi. Oligomenorea adalah siklus menstruasi dengan durasi lebih dari 35 hari. Volume perdarahan umumnya lebih sedikit dari volume perdarahan menstruasi biasanya. Gangguan jenis ini berakibat ketidaksuburan dalam jangka panjang karena sel telur jarang diproduksi sehingga tidak terjadi pembuahan. Oligomenorea tidak berbahaya pada wanita, namun dapat berpotensi sulit hamil karena tidak terjadi ovulasi (Sarwono, 2010).

Gangguan hormonal, status gizi, tinggi rendahnya IMT (Indeks Massa Tubuh), dan tingkat stress adalah faktor-faktor yang mengakibatkan timbulnya gangguan siklus menstruasi (Gharravi, 2009). Terdapat hubungan antara IMT dengan siklus menstruasi. Penurunan IMT berakibat pada peningkatan durasi siklus menstruasi (Sinha et al., 2011). Seseorang dengan status gizi overweight berisiko mengalami anovulatory chronic (Karyadi, 2007). Wanita dengan kondisi ini, cenderung memiliki sel - sel lemak yang lebih banyak sehingga produksi hormon estrogen juga menjadi berlebih. Adapun wanita dengan status gizi underweight, cenderung kekurangan sel lemak sehingga produksi hormon estrogen berkurang. Hal ini berdampak pada kejadian ketidakteraturan siklus menstruasi (Evan., 2011). Tingkat stres berhubungan dengan siklus menstruasi karena stres berhubungan dengan tingkat emosi, alur berpikir, dan kondisi batin seseorang. Faktor stres dapat mempengaruhi produksi hormon kortisol yang berpengaruh pada produksi hormon estrogen wanita (Sherwood, 2007). Hasil penelitian menyebutkan bahwa sekitar $22,1 \%$ wanita dengan gangguan psikologis, mengalami siklus menstruasi tidak teratur (Barron et al, 2008). Adapun tujuan penelitian untuk mengetahui faktor yang paling dominan mempengaruhi siklus menstruasi pada remaja putri tingkat III di STIKes Hutama Abdi Husada Tulungagung.

\section{METODE}

Desain penelitian adalah cross-sectional study. Adapun populasi dari penelitian adalah seluruh mahasiswi Tingkat III Program Studi S1 Keperawatan STIKes Hutama Abdi Husada Tulungagung. Teknik sampel yang digunakan adalah total sampling dengan kriteria inklusi adalah berusia $\leq 21$ tahun. Kriteria eksklusi penelitian yaitu mahasiswi yang belum menarche. Instrumen atau alat bantu penelitian berupa alat ukur timbangan, medline, dan kuesioner. Penelitian dilakukan tanggal 9 April 2018. Analisa data dilakukan dengan menggunakan uji chi-square dan multi variate analysis.

\section{HASIL}

Adapun karakteristik responden sebagai berikut:

. Tabel 1.

Karakteristik Responden

\begin{tabular}{lcc}
\hline Karakteristik Responden & f & $\%$ \\
\hline Umur (tahun) & 3 & 7 \\
19 & 18 & 45 \\
20 & 19 & 48 \\
21 & & \\
\hline Tingkat Stres & 23 & 57,5 \\
$\quad$ Stres & 17 & 42,5 \\
$\quad$ Tidak Stres & & \\
Status Gizi & 22 & 55 \\
$\quad$ Normal & 18 & 45 \\
$\quad$ Tidak Normal & & \\
\hline Siklus Menstruasi & 31 & 77,5 \\
$\quad$ Teratur & 9 & 22,5 \\
$\quad$ Tidak teratur & &
\end{tabular}


Hubungan antara faktor-faktor yang mempengaruhi siklus menstruasi digambarkan dengan analisis bivariat dan multivariat. Hasil analisis bivariat menunjukkan bahwa tingkat stres dan status gizi berhubungan dengan siklus menstruasi.

Tabel 2.

Hasil analisis bivariate faktor-faktor yang berpengaruh pada siklus menstruasi $(n=40)$

\begin{tabular}{|c|c|c|c|c|c|c|}
\hline \multirow[t]{3}{*}{ Variabel } & \multicolumn{4}{|c|}{ Kriteria Siklus Menstruasi } & \multirow[t]{3}{*}{$\mathrm{RP}(95 \% \mathrm{CI})$} & \multirow[t]{3}{*}{$\mathrm{p}$ value } \\
\hline & \multicolumn{2}{|c|}{ Teratur } & \multicolumn{2}{|c|}{ Tidak Teratur } & & \\
\hline & $\mathrm{f}$ & $\%$ & $\mathrm{f}$ & $\%$ & & \\
\hline \multicolumn{7}{|l|}{ Umur (tahun) } \\
\hline 19 & 3 & 9,7 & 0 & 0 & & 0,386 \\
\hline 20 & 14 & 45,2 & 4 & 44,4 & & \\
\hline 21 & 14 & 45,2 & 5 & 55,6 & & \\
\hline \multicolumn{7}{|l|}{ Tingkat Stres } \\
\hline Tidak Stres & 10 & 32,3 & 7 & 77,8 & 1 & \\
\hline Stres & 21 & 67,7 & 2 & 22,2 & $4,7(1,1-20,0)$ & $0,015^{*}$ \\
\hline \multicolumn{7}{|l|}{ Status Gizi } \\
\hline Normal & 21 & 67,7 & 1 & 11,1 & 1 & $0,026^{*}$ \\
\hline Tidak Normal & 10 & 32,3 & 8 & 88,9 & $2,8(1,6-4,8)$ & \\
\hline
\end{tabular}

*bermakna secara statistik

Analisis mutivariat dilakukan untuk mengetahui variabel-variabel yang paling mengetahui hubungan antara variabel dominan dalam mendeskripsikan hubungan dependen dan independen secara sebab dan akibat.Hasil analisis multivariat bersamaan.Analisis ini dilakukan untuk ditunjukkan dalam tabel 3 berikut.

Tabel 3.

Hasil Analisis Multivariate Faktor-Faktor yang Mempengaruhi Siklus Menstruasi

\begin{tabular}{lccc}
\hline Nama Variabel & \multicolumn{3}{c}{$\begin{array}{c}\text { Odds Ratio } \\
(95 \% \text { CI })\end{array}$} \\
\cline { 2 - 4 } & Model (1) & Model $(2) \Delta$ & Model (3) \\
\cline { 2 - 4 } Status Gizi & $27,96^{*}$ & $37,12 *$ & $18.95^{*}$ \\
& $(2,23-350,85)$ & $(2,38-354,64)$ & $(1.84-153.30)$ \\
Tingkat Stres & 0,010 & 0,008 & 0,012 \\
& 14,15 & 15.03 & \\
Umur & $(1,57-127,49)$ & $(1.61-117.26)$ & 0,002 \\
\hline p value & 0,018 & 0,017 & 22,9 \\
Pseudo $R^{2}(\%)$ & 0,997 & 0,0002 & 36.9 \\
AIC & 0,0017 & 40,2 & \\
\hline
\end{tabular}

* bermakna secara statistik

$\Delta$ goodfit model

Berdasarkan hasil analisis regresi logistik menunjukkan bahwa model terbaik adalah model ke-2.Variabel status gizi dan tingkat stres merupakan variabel yang paling besar pengaruhnya dalam siklus menstruasi. Kedua variabel tersebut dapat menggambarkan siklus menstruasi sebesar 40,2\% sedangkan sisanya, yaitu sebesar $50,8 \%$ disebabkan oleh faktor risiko lain yang tidak diteliti dalam penelitian ini.

\section{PEMBAHASAN}

Tingkat stres menimbulkan ketidakteraturan siklus menstruasi.Stres merupakan respon tubuh yang tidak dapat dijelaskan secara spesifik. Respon tersebut muncul akibat adanya stressor atau rangsangan terhadap faktor-faktor yang mengancam sistem pertahanan homeostatis (Sherwood., 2012). Stres berakibat timbulnya perubahan sistemik tubuh, terutama sistem saraf dalam 
hipotalamus. Adanya stres akan mempengaruhi produksi hormon prolaktin yang secara langsung berhubungan dengan aktivitas elevasi kortisol basal dan menimbulkan penurunan hormon LH. Selanjutnya hal ini berefek pada timbulnya gangguan siklus menstruasi (Kusmiran, 2014).

Berdasarkan hasil penelitian dan teori, didaptkan kesimpulan bahwa terdapat hubungan yang signifikan antara tingkat stres dengan siklus menstruasi pada remaja putri tingkat III di STIKes Hutama Abdi Husada Tulungagung.Penelitian ini sejalan dengan hasil penelitian yang dilakukan oleh Sekar Pinasti (2012) bahwa terdapat hubungan yang signifikan antara tingkat stres dengan siklus menstruasi.Menurut peneliti hal ini membuktikan bahwa tingkat stres seseorang dapat mempengaruhi siklus menstruasi setiap bulannya.Hal tersebut sesuai dengan data yang diperoleh bahwa ada dari beberapa remaja putri ada yang mengalami stres dan juga memiliki siklus menstruasi tidak teratur.Namun kebanyakan remaja putri tingkat III tidak mengalami stres dan memiliki siklus menstruasi teratur.

Ketidakteraturan siklus menstruasi tersebut harus segera ditangani agar tidak terjadi berkepanjangan. Pada seseorang yang mengalami stres disarankan untuk mengurangi faktor yang dapat menyebabkan stres dengan cara mengontrol emosi. Dengan mengontrol emosi dapat mempengaruhi produksi hormon kortisol menjadi normal. Dengan begitu seseorang tidak akan mengalami stres dan akan mempengaruhi siklus menstruasinya menjadi teratur.

Siklus menstruasi dipengaruhi oleh hormonal.Terutama hormon estrogen dan progesteron, kedua hormon tersebut dikeluarkan secara siklik oleh ovarium pada masa reproduksi.Status gizi juga bersinergi dengan siklus menstruasi. Siklus ovulasi supaya dapat berlangsung normal dan teratur, tubuh memerlukan 22\% lemak dan IMT lebih dari $19 \mathrm{~kg} / \mathrm{m}^{2}$. Sel - sel lemak berfungsi untuk membantu memproduksi estrogen yang diperlukan bagi proses ovulasi dan berjalannya siklus menstruasi (Coad., 2007).

Polimenorea dan oligomenorea mengindikasikan adanya ketidaknormalan dalam sistem metabolisme tubuh. Efek jangka panjangnya adalah susah untuk hamil. Jika terjadi siklus pendek, berisiko terjadi unovulasi sedangkan jika terjadi siklus panjang, mengindikasikan sel telur jarang diproduksi. Keduanya mengindikasikan gangguan kesuburan pada wanita (Atikah dan Misaroh., 2009).Berdasarkan hasil penelitian dan teori, menunjukkan terdapat kaitan signifikan antara status gizi dengan dengan siklus menstruasi pada remaja putri tingkat III di STIKes Hutama Abdi Husada Tulungagung. Penelitian ini sejalan dengan hasil penelitian yang dilakukan oleh Harahap (2013) bahwa ada hubungan yang signifikan antara indeks massa tubuh dengan keteraturan maupun ketidak teraturan siklus menstruasi.

Sebagian besar responden penelitian ini memiliki status gizi normal dan mengalami siklus menstruasi yang teratur.Namun ada pula responden dengan status gizi tidak normal dan mengalami siklus tidak teratur.Dari ketidakteraturan siklus menstruasi tersebut harus segera diantisipasi agar tidak terjadi berkepanjangan.Pada saat seseorang mengalami ketidaknormalan status gizi dianjurkan segera menstabilkan status gizinya.Karena dapat memperbaiki fungsi reproduksi, termasuk perubahan hormon dan sel lemak. Menurut peneliti hal ini membuktikan bahwa status gizi seseorang dapat mempengaruhi siklus menstruasi setiap bulannya. Berarti dengan seseorang memiliki status gizi normal akan mempengaruhi siklus menstruasinya menjadi teratur.

\section{SIMPULAN DAN SARAN}

\section{Simpulan}

Analisis bivariate antara stres dan siklus menstruasi pada mahasiswi tingkat IIIi STIKes Hutama Abdi Husada Tulungagung tahun 2018, menunjukkan bahwa mahasiswi yang mengalami stres berisiko 4,7 kali untuk mengalami siklus menstruasi tidak teratur (95\% CI: $1,1-20,0)$. Analisis bivariate antara status gizi dan siklus menstruasi pada mahasiswi tingkat III STIKes Hutama Abdi Husada Tulungagung tahun 2018,menunjukkan bahwa mahasiswi yang memiliki status gizi tidak normal (overweight/underweight) berisiko 2,8 kali untuk mengalami siklus menstruasi tidak teratur $(95 \%$ CI: 1,6 - 4,8). Analisis multivariate menunjukkan bahwa status gizi 
dan stres merupakan faktor yang paling dominan mempengaruhi siklus menstruasi dengan nilai Pseudo $\mathrm{R}^{2}=40,2 \%$.

\section{Saran}

Rekomendasi bagi dinas kesehatan dan puskesmas diharapkan lebih meningkatkan pemberian informasi dalam peningkatan kesehatan reproduksi terutama pada gangguan siklus menstruasi.

\section{DAFTAR PUSTAKA}

Alimul Hidayat. 2008. Metode Penelitian Keperawatan dan Teknik Analisa Data.Jakarta : Salemba Medika

Almatsier, S. 2010. Prinsip Ilmu Gizi. Jakarta : Gramedia Pustka Utama.

Arikunto, Suharsimi. 2008. Prosedur Penelitian Suatu Pendekatan Praktik. Jakarta: Rineka Cipta.

Aryani, Ratna. 2010. Kesehatan Remaja Problem dan Solusinya.Jakarta : Salemba Medika

Banudi, La. 2013. Gizi Kesehatan Reproduksi. Jakarta : EGC

Barron et al. 2008. Associations Between Psychiartric Disorders And Menstrual Cycle Characteristics. Arch Psychiatr Nurs.

Cakir, M. 2009. Prevalensi Kejadian Gangguan Menstruasi Berdasarkan Indeks Masa Tubuh (IMT) pada Siswa Kelas VII SMP.Jurnal Kebidaan Vol 1 No 58-64.

Carolin.2010. Gambaran Tingkat Stres pada Mahasiswa Kedokteran Universitas Sumatera Utara.Skripsi.Tidak dipublikasikan.Medan : Universiitas Sumatera Utara

Fitria, A. 2007.Panduan Lengkap Kesehatan Wanita. Yogyakarta : Gala Ilmu Semesta

Gharravi. 2009. Menstrual Cycle Patterns of Collage Students in Gorgan-Northeast of Iran : Identify its Association with
Sociodemographic Factors. Articel in Erciye Tip Dergisi 31(4):331-338

Gibson. 2007. Iprinciples of Nutritional Assesment. Second Edition. Oxford University Press, New York

Habeeb, Kholoud Abdulrahman. 2010. Prevalence of Stressors Among Female Medical Student. Journal of Taibah University Medical Sciences. 5(2) : 110-119

Harahap, Juliana Sari. 2013. Hubungan Indeks Massa Tubuh dengan Siklus Menstruasi Pada Mahasiswi Fakultas Kedokteran Universitas Sumatera Utara. Skripsi.Tidak dipublikasikan. Medan: Universitas Sumatera Utara

Intan \& Iwan.2012. Kesehatan Reproduksi untuk Mahasiswa Kebidanan dan Keperawatan.Jakarta : Salemba Medika.

Kusmiran, E. 2011.Kesehatan Reproduksi Remaja Dan Wanita. Jakarta: Salemba Medika.

Lavibond, S. H. \& Lavibond, P. F. 1995.Manual for Depression Anxiety and Stress Scale. 2thed. Sydney: Psychology Foundation.

Maramis, 2009.Catatan Ilmu Kedokteran Jiwa. Edisi 2.Surabaya : Airlangga

Notoatmodjo, S. 2010. Metodeologi Penelitian Kesehatan. Jakarta : EGC

Nursalam. 2008. Konsep dan Penerapan Metodologi Penelitian Ilmu Keperawatan. Jakarta : Salemba Medika

Nurul. 2017. Hubungan antara Stres dengan Pola Siklus Menstruasi Mahasiswi Fakultas Kedokteran Universitas Andalas.Jurnal Kesehatan Andalas.

Patil et al. 2013.Menstrual Pattern among Adolescent Girl In Rural Area Of Bijapur. Al Ameen J med Sci 
Pinel, J.P.J. 2009.Stres dan Kesehatan Dalam : Biopsikolgi Edisi ke-7. Yogyakarta : Pustaka Pelajar

Prawirohardjo, S. 2007. Ilmu kandungan.Edisi 2.Jakarta :Yayasan Bina Pustaka

Proverawati, Atikah. 2009. Menarche Menstruasi Pertama Penuh Makna.Yogyakarta : Mulia Medika

Rigon et al. 2012.Menstrual Pattern And Menstrual Disorders Among Adolescents : An Update Of The Italian Data. Italian Journal of Pediatrics

Riskesdas.2007. Riset Kesehatan Dasar (RISKESDAS) Tahun 2007. Jakarta

Sahmin.2017. Prevalensi Gangguan Menstruasi pada Remaja Putri di SMK YPKK Sleman.Skripsi. Tidak Dipublikasikan. Yogyakarta : STIKes Jendral Achmad Yani

Sarwono. 2008. Ilmu Kandungan.Jakarta : Yayasan Bima Pustaka

Sekar, Pinasti. 2012. Hubungan Antara Tingkat Stres Dengan Siklus Menstruasi Pada Siswi Kelas 2. Skripsi. Tidak Dipublikasikan. Semarang : Fakultas Kedokteran Muhammadiyah Semarang.

Sherwood, L. 2009. Human Physiologi From Cells To Cells To System. West Virginia Thomsan. Publishing inc 2009.
Sinha et al. 2011.Adposity Measures And Menstrual Cycle :Do We Envisage A Relation?. Journal Of Anthropologi.

Sudrajat. 2008. Pengetahuan Pendekatan, Strategi, Metode, Teknik dan Model Pembelajaran. Jakarta : Rineka Cipta

Sugiyono. 2011. Metode Penelitian Kuantitatif, Kualitatif dan $R \& D$. Bandung : Alfabeta

Suhardjo. 2007. Berbagai Cara Pendidikan Gizi. Jakarta : Bumi Aksara

Supriasa, I. 2007. Penilaian Status Gizi.Bandung : Alfabeta

Tiara. 2016. Hubungan Indeks Massa Tubuh (IMT) dengan Siklus Menstruasi pada Mahasiswi Fakultas Kedokteran Angkatan 2013 universitas Malahayati Bandar Lampung. Skipsi.Tidak dipublikasikan. Badar Lampung : universitas Malahayati

Surnaryo. 2013. Psikologi untuk Keperawatan. Jakarta : EGC

Waryana, 2010.Gizi Reproduksi. Yogyakarta : Pustaka Rihama

Winkjosastro, S. 2012. Ilmu Kandungan. Jakarta : Yayasan Bina Pustaka 